Pesq. Vet. Bras. 28(10):508-514, outubro 2008

\title{
Clonal study of avian Escherichia coli strains by flic conserved-DNA-sequence regions analysis ${ }^{1}$
}

\author{
Tatiana Amabile de Campos², Gerson Nakazato², Eliana Guedes Stehling², \\ Marcelo Brocchi ${ }^{2}$ e Wanderley Dias da Silveira ${ }^{2 *}$
}

\begin{abstract}
Campos T.A., Nakazato G., Stehling E.G., Brocchi M. \& Silveira W.D. 2008. Clonal study of avian Escherichia coli strains by fliC conserved-DNA-sequence regions analysis. Pesquisa Veterinária Brasileira 28(10):508-514. Departamento de Microbiologia e Imunologia, Instituto de Biologia, Cx. Postal 6109, Universidade Estadual de Campinas, Cidade Universitária Zeferino Vaz s/n, Barão Geraldo, Campinas, SP 3081-862, Brazil. *Corresponding author: wds@ @unicamp.br

The clonal relationship among avian Escherichia colistrains and their genetic proximity with human pathogenic E. coli, Salmonela enterica, Yersinia enterocolitica and Proteus mirabilis, was determined by the DNA sequencing of the conserved 5' and 3'regions fliC gene (flagellin encoded gene). Among 30 commensal avian E. coli strains and 49 pathogenic avian E. coli strains (APEC), 24 commensal and 39 APEC strains harbored fliC gene with fragments size varying from $670 \mathrm{bp}$ to $1,900 \mathrm{bp}$. The comparative analysis of these regions allowed the construction of a dendrogram of similarity possessing two main clusters: one compounded mainly by APEC strains and by $\mathrm{H}$-antigens from human E. coli, and another one compounded by commensal avian E. coli strains, S. enterica, and by other $\mathrm{H}$-antigens from human $E$. coli. Overall, this work demonstrated that fliC conserved regions may be associated with pathogenic clones of APEC strains, and also shows a great similarity among APEC and $\mathrm{H}$-antigens of $E$. coli strains isolated from humans. These data, can add evidence that APEC strains can exhibit a zoonotic risk.
\end{abstract}

INDEX TERMS: APEC, clonal analysis, fliC gene.

RESUMO. - [Estudo clonal de Escherichia coli aviário por análise de seqüências de DNA conservadas do gene flic.] A relação clonal entre linhagens de Escherichia coli de origem aviária e sua proximidade genética com $E$. coli patogênica para humanos, Salmonella enterica, Yersinia enterocolitica e Proteus mirabilis foi determinada através da utilização das seqüências conservadas 5' e 3 ' do gene fliC (responsável pela codificação da flagelina). Entre as 30 linhagens comensais de E. coli aviária e as 49 linhagens patogênicas de E. coli para aves (APEC), 24 linhagens comensais e 39 APEC apresentaram o gene fliC, que foi encontrado em tamanhos que variam de 670pb a $1900 \mathrm{pb}$. Um dendrograma representando similaridade genética foi obtido a partir do seqüenciamento das regi-

\footnotetext{
${ }^{1}$ Received on October 26, 2007.

Accepted for publication on June 19, 2008.

2 Departamento de Microbiologia e Imunologia, Instituto de Biologia, Cx. Postal 6109, Universidade Estadual de Campinas (Unicamp), Cidade Universitária Zeferino Vaz s/n, Barão Geraldo, Campinas, SP 3081862, Brazil. *Corresponding author: wds@unicamp.br
}

ões 5' e 3' conservadas do gene fliC das linhagens de $E$. coli de origem aviária, das seqüências dos antígenos $\mathrm{H}$ de E. coli de origem humana, de S. enterica, Y. enterocolitica e de $P$. mirabilis. A análise do dendrograma demonstrou que este apresenta dois grupos principais: um composto principalmente por isolados APEC e por antígenos $\mathrm{H}$ de $E$. coli de origem humana e outro formado por isolados comensais de E. coli aviária, S. enterica e por antígenos $\mathrm{H}$ de E. coli. No geral, o presente trabalho demonstrou que as regiões conservadas do gene fliC podem estar associadas à diferenciação clonal de linhagens de $E$. coli aviária, e que existe uma grande similaridade genética entre estas linhagens e antígenos $\mathrm{H}$ de $E$. coli humana. Estes dados podem adicionar evidências de que linhagens APEC podem apresentar riscos zoonóticos.

TERMOS DE INDEXAÇÃO: APEC, análise clonal, gene flic.

\section{INTRODUCTION}

Avian pathogenic Escherichia coli (APEC) strains cause a variety of diseases in poultry, including respiratory tract 
infection, septicemia, omphalitis, swollen-head syndrome and enteritis, being responsible for significant economic losses in the poultry industry (Gross 1994). The pathogenesis and role of virulence factors present in these $E$. coli strains were not fully elucidated yet, although considerable efforts have been made in recent years to establish the mechanisms of pathogenesis (Dho-Moulin \& Fairbrother 1999). Besides, clonal population studies based on REP and ERIC-PCR sequences, PFGE, and MLEE have demonstrated that APEC strains present a complex structure that could represent the reason for the absence of a clear definition of pathotypes in these strains (White et al. 1993, Ngeleka et al. 1996, Moura et al. 2001, Silveira et al. 2002, Brito et al. 2003, Ewers et al. 2004, Brochi et al. 2006).

The genes expressing proteins located on the surface of bacterial cells are candidates as potential biomarkers to assess intra-species genetic variation, because such proteins show a much greater rate of divergence in the amino acid sequence than those located internally. Among surface bacterial cell proteins, flagella proteins have been used as a target to population variation studies (Winstanley \& Morgan 1997).

The flagellum is the cell structure responsible for motility in the majority of bacterial species. Flagellar activity is coupled to a sensory apparatus in a control system that allows movement of a cell towards attractive environments and away from repellent ones. The basic structure of bacterial flagella can be sub divided into three parts: (i) the basal body, which consists of a series of rings and a central rod, is anchored in the inner and outer membranes of the cell; (ii) the hook is located external to the cell and provides the link between the basal body and filament; and (iii) the flagellar filament, the largest portion of the flagella, consists of repeating sub-units of the protein flagellin in a helical arrangement and that often extends many times the length of the cell (Macnab 1992, Winstanley \& Morgan 1997).

Flagellin proteins have a distinctive domain structure, comprising conserved $\mathrm{N}$ - and $\mathrm{C}$-terminal regions, and a central domain that may vary considerably in both amino acid sequence and size (Macnab 1992, Winstanley \& Morgan 1997). In Escherichia coli, flagellin proteins are encoded by the fliC gene that has conserved 5' and 3' regions and a high polymorphic central region (Kuwajima et al. 1986, Winstanley \& Morgan 1997, Fields et al. 1997, Wang et al. 2003, Botelho et al. 2003, Amhaz et al. 2004, Tominaga 2004, Beutin et al. 2005, Moreno et al. 2006). Joys (1985) suggested that the accumulation of random mutations maintained by functional pressure absence is responsible by the polymorphism presented in the central region of fliC gene. However, Honda et al. (1999) demonstrated a primordial function for the central region of flagellin. They proposed the hairpin model, suggesting that flagellin monomers fold into a hairpin-like conformation, with the conserved $\mathrm{N}$ - and $\mathrm{C}$ - domains located prevalently on the inside and being responsible for defining the basic filament structure, whilst the central, variable domain is exposed on the surface. Reid et al. (1999) and Strauch \&
Beutin (2006) suggested that host immune selective pressure, recombination and lateral genetic transfer would be responsible for the polymorphism of the fliC central region and, consequently, by the flagellin polymorphism. The genetic variation of the fliC central region reflects the restriction fragment length polymorphism (RFLP) variability presented by $E$. colistrains belonging to the same $\mathrm{H}$ antigen. Such variability renders difficult the development of primers and molecular test to detect $\mathrm{H}$ antigens associated with pathogenic clones of $E$. coli (Fields et al. 1997, Wang et al. 2003, Tominaga 2004, Beutin et al. 2005, Moreno et al. 2006). The fliC gene has been used in bacterial systematic and population genetic studies because its variability reflects the selective procedures involved on the bacterial flagella antigen ( $\mathrm{H}$ antigen) diversity. For phylogenetic trees and intra-specific population variation analysis the fliC sequences are divided in three regions: two corresponding to the 5' and 3' conserved regions and one corresponding to the central region (Winstanley \& Morgan 1997).

The purpose of the present study was to establish the clonal relationship of commensal and pathogenic avian $E$. coli strains (APEC) by the DNA sequencing and comparison of the fliC conserved 5' and 3' regions. The fliC of the E. coli $\mathrm{H}$-serotypes, of nine Salmonella enterica serovars and of the flagellin gene sequences of Proteus mirabilis and Yersinia enterocolitica were also used to assess the clonal population analysis of the commensal strains and APEC strains herein studied and to verify the genetic relationship of these avian $E$. coli strains with human E. coli and enterobacteria.

\section{MATERIALS AND METHODS}

\section{Bacterial strains}

Twenty-four septicemic (S), 14 swollen head syndrome (SHS), and 11 omphalitis (O) Escherichia coli strains isolated from different outbreaks, and 30 commensal strains $(C)$ isolated from foals showing no signs of any of the above mentioned diseases and belonging to the Laboratory of Microbial Molecular Biology, DMI, UNICAMP, were studied in the present work. Strains from septicemic cases were isolated from liver, air sac and lung; swollen head syndrome strains were isolated from infra-orbitary sinuses and omphalitis strains were isolated from the yolk sacs of embryos chickens; commensal strains were collected from the cloacae region. All strains were kept at $-80^{\circ} \mathrm{C}$ in LB medium containing $15 \%$ glycerol final concentration.

\section{Motility assay}

All avian E. coli strains had their motility tested. Each strain was cultivated on MacConkey agar plates for 18 hours at $37^{\circ} \mathrm{C}$. One colony forming unit (CFU) of each strain was inoculated in LB medium added of $0.3 \%$ agar with a sterile needle and incubated for 18 hours at $37^{\circ} \mathrm{C}$. Motility was determined as the cloudy growth of each strain in LB (Sambrook \& Russel 2001) medium containing $0.5 \%$ agar.

\section{Genomic DNA extraction and detection of the fliC gene by PCR}

Genomic DNA was extracted and purified as described previously (Ausubel et al. 1988). Extracted DNA was carefully 
harvested in sterilized deionized water and its integrity was determined by using $0.7 \%$ agarose gels in TE buffer as described by Sambrook \& Russell (2001).

The detection of the flic gene on each strain was accomplished with polymerase chain reactions (PCR) by using the primers fliC1 (5'- ATGGCACAAGTCATTAATACCCAAC-3') and fliC2 (5'- CTAACCCTGCAGCAGAGACA-3') described by Fields et al. (1997). E. coli K12 HB101 strain was used as a positive control for the detection of fliC. The PCR reactions were prepared to contain 20ng of DNA, $10 \mathrm{pmol}$ of each primer, $10 \mathrm{mM}$ of the four deoxynucleoside triphosphates (Invitrogen), PCR buffer (Invitrogen), and 1 unit of Taq-polymerase high fidelity (Invitrogen). All amplification reactions were performed at a "Mastercyle" thermocycle (Ependorff). PCR were performed in 35 cycles of amplification as follow: $1 \mathrm{~min}$ at $95^{\circ} \mathrm{C}, 1 \mathrm{~min}$ at $61^{\circ} \mathrm{C}$, and $2 \mathrm{~min}$ at $72^{\circ} \mathrm{C}$. PCR products were analyzed by submersed gel agarose (1.0\%) electrophoresis as described by Sambrook et al. (1989).

\section{fliC gene sequencing}

All fliC genes fragments amplified by PCR were purified by using the GFX purification kit (GE - Healthcare Amershan). After purification, 600ng of PCR products were submitted to the DNA sequencing reaction after adding $4 \mu \mathrm{L}$ of ET (Dye Terminator, GE, Healthcare Amershan), 10pmol of primer, and sterile deionized water to a $10 \mu \mathrm{L}$ final volume. The PCR-sequencing reactions, performed at the "Mastercyle" thermocycle (Ependorff) in 96 wells sequencing-plates, consisted of 30 cycles as follow: $20 \mathrm{sec}$ at $90^{\circ} \mathrm{C}, 15 \mathrm{sec}$ at $50^{\circ} \mathrm{C}$, and $1.20 \mathrm{~min}$ at $60^{\circ} \mathrm{C}$. Each fliC fragment was sequenced forward (primer: 5'ATGGCACAAGTCATTAATACCCAAC-3') and reverse (primer: 5'- CTAACCCTGCAGCAGAGACA-3') at least three times.

\section{Precipitation of the PCR-sequencing products}

After PCR-sequencing, each product was precipitated as follow: $200 \mu \mathrm{L}$ of Ammonium acetate 7.5M was added on each well of the sequencing plate. The sequencing plate was mixed in vortex and spun at 900rpm. $55 \mu \mathrm{L}$ of ethanol $100 \%$ (room temperature) were added in each well, and the plate was mixed and maintained at room temperature with absence of light for 30 minutes. The plate was centrifuged for 60 minutes $(4,000$ $\mathrm{rpm}$ at $20^{\circ} \mathrm{C}$ ), and the supernatant discarded. $100 \mu \mathrm{L}$ of ethanol $70 \%\left(4^{\circ} \mathrm{C}\right)$ were added in each well and the plate was again submitted to centrifugation $\left(4,000 \mathrm{rpm}\right.$ at $\left.4^{\circ} \mathrm{C}\right)$ during 10 minutes. The supernatant was discarded, and the plate maintained at $4^{\circ} \mathrm{C}$ during 2 hours in the absence of light. $10 \mu \mathrm{L}$ of loading solution were added in each well, the plate was carefully mixed (900 rpm) and maintained at $4^{\circ} \mathrm{C}$ light protected, during 3 hours. The sequencing samples were then processed on the MegaBace apparatus (GE Healthcare Bio-Sciences, Little Chalfont, UK) to sequence reading.

\section{DNA-sequence analysis}

The fliC sequences obtained were analyzed by the Bioedit software (Hall 1999). For each strain, it was obtained one consensus sequence resulting from the three sequencing reactions realized. All concensus sequences from avian $E$. coli strains, fliC sequences described for the $E$. coli $\mathrm{H}$-antigen (Wang et al. 2003), flic sequence described for Salmonella enterica serovars (Popoff et al. 1997), and flagellin DNA sequences described for Yersinia enterocolitica (Kapatral \& Minnichi 1995) and Proteus mirabilis (Belas \& Flaherty 1994) were aligned to obtaining the final dendrogram of similarity.

\section{DNA-similarity analysis and dendrogram obtaining}

The dendrogram was generated with the Mega 3.1 software (Kumar et al. 2004) by the UPGMA algorithm.

\section{RESULTS}

Forty-two avian Escherichia coli strains presented positive motility after 18 hours of growth into LB $0.3 \%$ agar at $37^{\circ} \mathrm{C}$. Among these strains, 15 were commensal, 11 were isolated from septicemic cases, 11 were isolated from swollen head syndrome cases (SHS), and 6 were omphalitis strains (Table 1).

The fliC gene was detected in 62 strains by the PCR assays (Table 1). Fragments varying from 670 bp to 1,900 bp were detected (Table 1 and Fig.1). Among fliC ${ }^{+}$strains, 24 were commensal, 16 were septicemic, 14 were SHS, and 9 were omphalitis strains.

Thirty-six mobile strains harbored the fliC gene, $26 \mathrm{fliC}^{+}$ strains showed to have negative motility and seven mobile strains were negative for fliC amplification.

Table 1. Motility and flic detection by PCR among avian Escherichia coli strains

\begin{tabular}{|c|c|c|c|c|c|}
\hline Strain & Motility & fliC (bp) & Strain & Motility & fliC (bp) \\
\hline C1 & + & 1020 & S11 & - & - \\
\hline C2 & + & - & S12 & - & - \\
\hline C3 & + & 1740 & S13 & + & 1240 \\
\hline C4 & - & 1415 & S14 & - & 1240 \\
\hline C5 & - & 1515 & S15 & + & 1240 \\
\hline C6 & - & 1740 & S16 & + & - \\
\hline C7 & + & 1415 & S17 & - & - \\
\hline C8 & + & 1515 & S18 & + & - \\
\hline C9 & - & 1620 & S19 & - & 1740 \\
\hline C10 & + & 1400 & $\mathrm{~S} 20$ & - & - \\
\hline C11 & + & 1300 & $\mathrm{~S} 21$ & - & 1740 \\
\hline C12 & - & 1750 & S22 & - & 1740 \\
\hline C13 & - & 1750 & S23 & - & 1325 \\
\hline C14 & + & 1500 & S24 & - & 1740 \\
\hline C15 & - & 1500 & SHS1 & + & 1435 \\
\hline C16 & - & 1750 & SHS2 & + & 1435 \\
\hline C17 & + & 1500 & SHS3 & + & 670 \\
\hline C18 & - & 1900 & SHS4 & + & 670 \\
\hline C19 & - & 1900 & SHS6 & + & 2025 \\
\hline C20 & - & - & SHS7 & + & 670 \\
\hline $\mathrm{C} 21$ & + & 1500 & SHS8 & + & 670 \\
\hline $\mathrm{C} 22$ & + & - & SHS9 & + & 1225 \\
\hline C23 & - & 1750 & SHS10 & + & 1225 \\
\hline C24 & + & - & SHS11 & - & 1435 \\
\hline $\mathrm{C} 25$ & + & 1400 & SHS12 & + & 2025 \\
\hline C26 & - & 1620 & SHS13 & - & 2025 \\
\hline $\mathrm{C} 27$ & + & - & SHS14 & - & 1435 \\
\hline $\mathrm{C} 28$ & - & 1400 & SHS15 & + & - \\
\hline C29 & + & 1400 & 01 & - & - \\
\hline C30 & - & - & $\mathrm{O} 2$ & - & 1740 \\
\hline S1 & + & 1420 & O3 & - & 1740 \\
\hline S2 & + & 1420 & $\mathrm{O} 4$ & + & 1300 \\
\hline S3 & + & 1325 & O5 & + & 1620 \\
\hline S4 & - & 1950 & O6 & + & 1500 \\
\hline S5 & + & 1420 & $\mathrm{O} 7$ & + & 1620 \\
\hline S6 & + & 1325 & $\mathrm{O} 8$ & - & 1500 \\
\hline S7 & - & - & O9 & + & 1620 \\
\hline S8 & + & 1325 & 010 & - & - \\
\hline S9 & + & 1420 & 011 & - & 1620 \\
\hline S10 & - & - & & & \\
\hline
\end{tabular}




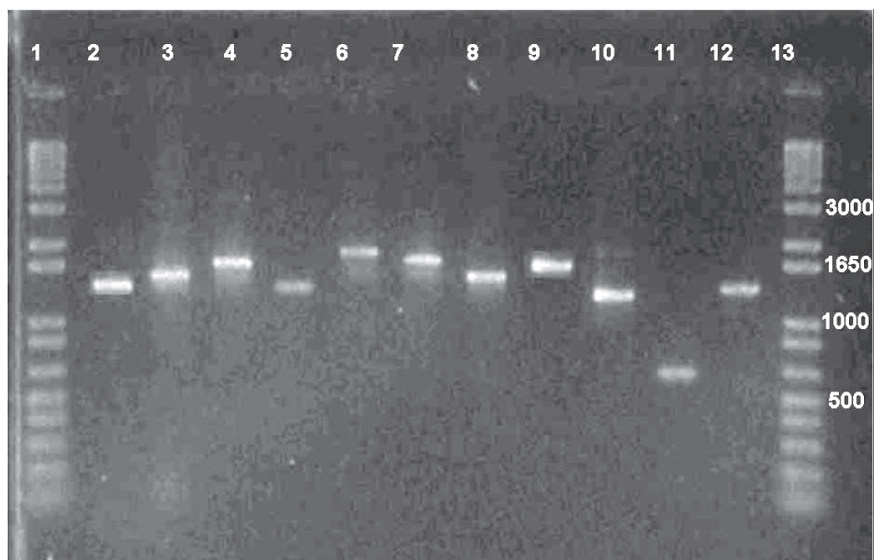

Fig.1. Agarose gel (1\%) with the fliC PCR products from avian Escherichia coli strains. 1: 1Kb ladder (bp); 2: C11 strain; 3: C15 strain; 4: C26 strain; 5: S3 strain; 6: C19 strain; 7: C23 strain; 8: S1 strain; 9: S19 strain; 10: S14 strain; 11: SHS2 strain; 12: SHS8 strain; 13: 1Kb ladder (bp).

About 400 bp of the fliC 5'region and 500bp of the fliC 3 ' region were sequenced by the described primers. All obtained sequences were analyzed with the Bioedith (Hall 1999) and BLAST (http://www.ncbi.nlm.nih.gov/blast) to verify the homology of the fliC gene. After the homology confirmation, all sequences were aligned together with the fliC sequence of $\mathrm{H}$-antigen from human $E$. coli, from 9 serovars of $S$. enterica, and with the flagellin sequences from $Y$. enterocolitica and $P$. mirabilis. The conserved sequences were used to obtain the dendrogram showed in Figure 2.

The dendrogram obtained presented four main clusters, named 1, 1A, 1A.1 and 1A.2 (Fig.2). Cluster 1 was compounded by four strains, two SHS (SHS1, SHS2), one commensal (C1), and one omphalitis (O6). Cluster 1.A possessed three commensal strains (C12, C21, C9), one SHS strain (SHS3), and the flagellin genes from $P$. mirabilis and $Y$. enterocolitica. Cluster 1.A.1 was compounded by 12 commensal (C14, C7, C15, C5, C28, C29, C25, C8, $\mathrm{C} 17, \mathrm{C} 4, \mathrm{C} 10, \mathrm{C} 22)$ strains, two septicemic (S1, S5), one omphalitis strain (O8), by six $\mathrm{H}$-antigens from human $E$. coli $(\mathrm{H} 21, \mathrm{H} 11, \mathrm{H} 27, \mathrm{H} 16, \mathrm{H} 8, \mathrm{H} 2)$ and by the fliC from the nine $S$. enterica serovars. Finally, cluster 1.A.3 was compounded by $38 \mathrm{H}$-antigens from human $E$. coli and by 38 avian E. coli strains. Among these, 8 strains were commensal (C11, C18, C23, C13, C6, C26, C19, C3), 14 were originated from septicemic cases (S24, S19, S15, S23, S9, S8, S3, S22, S21, S13, S6, S14, S2, S4), 9 were from SHS cases (SHS6, SHS8, SHS14, SHS13, SHS7, SHS11, SHS12, SHS10 e SHS4), and 7 were from omphalitis cases (O5, O4, O11, O3, O9, O7, e O2) (Fig.2).

\section{DISCUSSION}

In recent years, several works demonstrated the presence of genetic similarities among APEC strains, human Escherichia coli and other Enterobacteriaceae species, which suggested that APEC strains present a zoonotic risk (Stocki et al. 2002, Johnson et al. 2003, Mokady et al. 2005, Rodriguez-Siek et al. 2005). The aim of the present study was to verify if there is a genetic similarity, as determined by the DNA sequencing and comparison of the fliC gene among avian pathogenic $E$. coli and other strains of human bacterial pathogens such as E. coli, Salmonella enterica, Yersinia enterocolitica, and Proteus mirabilis. At the same time, the DNA sequencing and comparison of the fliC gene allowed us to insert the different APEC strains into clusters of similarity.

The PCR-amplified DNA-fragments of the different avian E. coli strains presented variable molecular weights (Table 1 and Fig.1). These data are in agreement with previous studies that demonstrated the high genetic polymorphism of fliC gene from E. coli. This polymorphism was attributed to the duplication of DNA sequences, genetic recombination and the presence of insertion elements in the central region of the fliC gene. All together, these genetic events would be responsible by the $\mathrm{H}$ antigen variability (Fields et al. 1997, Reid et al. 1999, Tominaga 2004, Beutin et al. 2005, Strauch \& Beutin 2006). However, the fragment variability observed in our study was different from that observed by Moreno et al. (2006), where fliC fragments varying from $1,300 \mathrm{bp}$ to $1,980 \mathrm{bp}$, among immobile $E$. coli strains, and from 1,190 to 4,170 among mobile $E$. coli strains were detected. Among the avian $E$. coli strains analyzed in the present work, fliC presented fragments varying from $670 \mathrm{bp}$ to $1,900 \mathrm{bp}$ (Table 1).

Although bacterial motility is considered as an indicative for the fliC gene presence, several $\mathrm{fliC}^{+}$bacterial strains did not present positive motility, and seven mobile strains did not have the fliC fragment amplified (Table 1). The absence of motility among $\mathrm{fliC}^{+}$strains may be attributed to the fliC non expression or to the non expression of other genes needed to bacterial motility or even the inexistence of these genes. Bacterial motility is a result from the expression of about 40 genes organized as a regulon (Macnab 1992). By the other hand, mobile strains with flic- genotype would suggest that fliC gene, at least for these strains, is not responsible by the expression of the flagellar filament or is the result of sequence variations in the primers annealing regions. We believe that the former hypothesis is more reliable since the sequences choose for the primers annealing are very much conserved. In addition, studies realized by Raitner (1998) and by Tominaga (2004) demonstrated that genes fImA and flkA are responsible by the flagellin expression in E. colistrains belonging to serogroups $\mathrm{H} 53$ and $\mathrm{H} 54$.

As it was previously observed by other research groups (Kuwajima et al. 1986, Fields et al. 1997, Reid et al. 1999, Botelho et al. 2003, Wang et al. 2003, Amhaz et al. 2004, Beutin et al. 2005, Moreno et al. 2006, Strauch \& Beutin 2006), our results also demonstrate, as determined by DNA-sequencing, that the fliC gene from avian E. coli strains presented conserved extremities and central regions with high polymorphism and as proposed by 


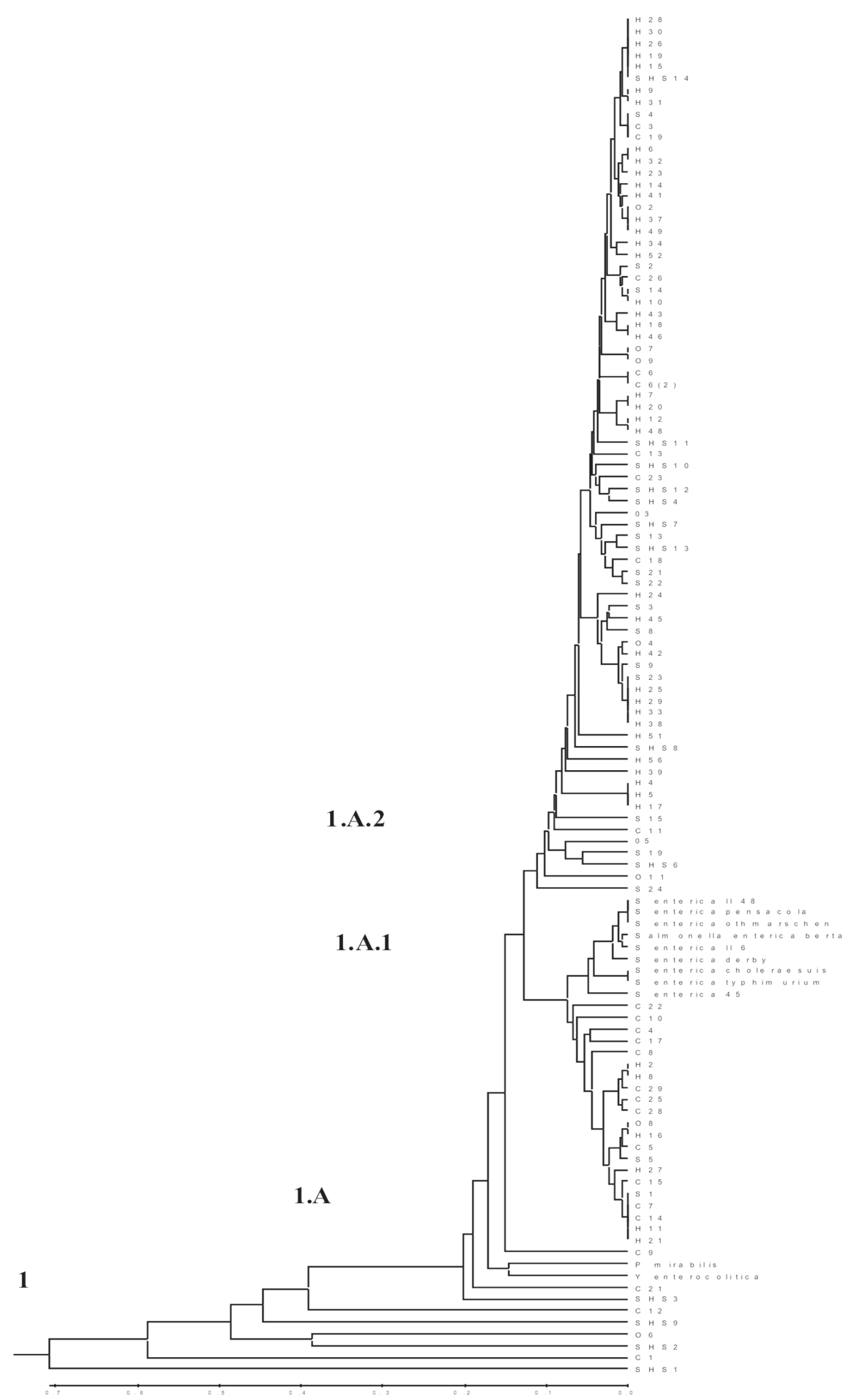

Fig.2. Dendrogram generated by 5' and 3' fliC gene regions sequencing of avian Escherichia coli strains, of fliC gene from $\mathrm{H}$ antigen from human E. coli, of fliC from Salmonella enterica serovars, from flagellin gene from Proteus mirabilis and from Yersinia enterocolitica, by using UPGMA algorithm (MEGA 3.1 software). 
Winstanley \& Morgan (1997) and Wang et al. (2003), we used the conserved fliC regions ( $5^{\prime}$ and $3^{\prime}$ ) to establish possible phylogenetic proximity among avian E. coli strains, E. coli $\mathrm{H}$-antigen, S. enterica, Y. enterocolitica, and $P$. mirabilis.

The dendrogram obtained by the comparison of these regions (Fig.2) demonstrated two distinct main groups: one (1.A.2) compounded, in its majority, by APEC strains (82\%) and other (1.A.1) compounded mainly by commensal avian E. coli strains (Fig.2). Thirty-eight (38) human H- E. coli (Wang et al., 2003) were also grouped in cluster 1.A.2. The genetic proximity of the fliC genes among APEC and human $E$. coli strains may suggests that the flagellar filament of these bacterial have a similar ancestor origin with the occurrence of divergence in the central region of fliC gene probably collaborating to differentiate the flagellar filament of these groups of bacteria. In this way, the genetic proximity of fliC conserved regions among APEC and human $E$. coli strains could indicated genetic similarity among these strains and may suggest a possible zoonotic risk to be present on APEC strains.

Clusters 1.A and 1.A.1 were compounded by 35 different strains. From these 14 were commensal avian $E$. coli strains, 6 were human $E$. coli $\mathrm{H}$-antigen, 9 were different $S$. enterica serovars, and three were APEC strains (one omphalitis, one septicemia and one swollen head syndrome) (Fig.2). All strains from cluster 1.A.1 presented $90 \%$ similarity. These data suggest that flagellar antigen from commensal avian $E$ coli presents similarity with $S$. enterica flagellar antigen, which, again, may indicate a similar genetic origin of commensal avian $E$. coli and $S$. enterica. These data are also corroborated by those published by Wang et al. (2003) who proposed, based on the same approach, to exist a common ancestor fliC gene for $E$. coli of human origin and S. enterica. Inside the same line of thought, genetics events probably occurred to differentiate among the APEC strains and E. coli H-antigen strains that were grouped in the cluster 1.A.2 (Fig.2). In this late case, the proximity among these strains supports the status of zoonotic bacteria to APEC, a hypothesis that is reinforced by the sharing of pathogenic traits among avian and human $E$. coli.

In conclusion, this work demonstrated that there is a genetic proximity among APEC and human $E$. colistrains, as assessed by the DNA sequencing and comparison of the fliC conserved regions of these strains. These data add evidences that APEC strains exhibits a zoonotic risk.

Acknowledgments.- This study was supported by a fellowship granted to Tatiana Amabile de Campos by Campinas State University (Unicamp), by Grant $n^{\circ} 303301 / 2002-3$ from the Brazilian Research Council (CNPq), and by Grant $n^{\circ}$ 03/08407-0 from Fundação de Amparo à Pesquisa do Estado de São Paulo (FAPESP).

\section{REFERENCES}

Amhaz J.M.K., Andrade A., Bando S.Y., Tanaka T.L., Moreira-Filho C.A. \& Martinez M.B. 2004. Molecular typing and phylogenetic analysis of enteroinvasive Escherichia coli using the fliC gene sequence. FEMS Microb. Lett. 235:259-264.
Ausubel F.M., Brente R., Kingstone R.E., Moore D.D., Smith J.A., Seidman J.G. \& Struhl K. 1988. Curr. Protoc. Mol. Biol., Green Publishing Associates, Brooklyn, N.Y.

Belas R. \& Flaherty D. 1994. Sequence and genetic analysis of multiple flagellin - encoding genes from Proteus mirabilis. Gene 148:33-41.

Beutin L., Struch E., Zimmermann S., Kaulfuss S., Schaudinn C., Männel A. \& Gelderblom H.R. 2005. Genetical and functional investigation of fliC genes encoding flagellar serotype $\mathrm{H} 4$ in wild type strains of Escherichia coli and in a laboratory E. coli K-12 strain expressing flagellar antigen type H48. BioMedCentral., http:// www.biomedcentral.com/1471-2180/5/4.

Botelho B.A., Bando S.Y., Trabulsi L.R. \& Moreira-Filho C.A. 2003. Identification of EPEC and non- EPEC serotypes in the EPEC O serogroups by PCR-RFLP analysis of the fliC gene. J. Microb. Meth. 54:83-93.

Brito B.G., Gaziri L. \& Vidotto M.C. 2003. Virulence factor and clonal relationships among Escherichia coli strains isolated from broiler chickens with cellulites. Infect. Immun. 71:4175-4177.

Brocchi M., Ferreira A., Lancellotti M., Stehling E.G., Campos T.A., Nakazato G., Pestana de Castro A.F. \& Silveira W.D. 2006. Typing of avian pathogenic Escherichia coli by REP-PCR. Pesq. Vet. Bras. 26:6973.

Dho-Moulin M. \& Fairbrother J.M. 1999. Avian pathogenic Escherichia coli (APEC). Vet. Res. 30:299-241.

Ewers C., JanBen T., KieBling S., Philpp H.C. \& Wieler L.H. 2004. Molecular epidemiology of avian pathogenic Escherichia coli (APEC) isolated from colisepticemia in poultry. Vet. Microb. 104:91-101.

Fields P.I., Bom H., Hughes L.O., Feng P. \& Swaminathan B. 1997. Molecular characterization of the gene encoding $\mathrm{H}$ antigen in Escherichia coli and development of a PCR-restriction of length polymorphism test of identification of E. coli O157: $\mathrm{H} 7$ and O157: NM. J. Clin. Microb. 35:1066-1070.

Gross W.B. 1984. Effect of a range of social stress severity on Escherichia coli challenge infection. Am. J. Vet. Res. 45:2074-2076.

Hall T.A. 1999. BioEdit a user friendly biological sequence alignment editor and analysis program for Windows 95/98/NT. Nucl., Ac. Symp. Ser. 41:95-98.

Honda S., Uedaira H., Vondervistzt F., Kidokoro S. \& Namba K. 1999. Folding energetics of a multidomains protein, flagellin. J. Mol. Biol. 293:719-732.

Johnson J.R., Murray A.C., Gajewski A., Sullivan M., Snippes P., Kuskowisk M.A. \& Smith K.E. 2003. Isolation and molecular characterization of nalidixic-acid resistant extraintestinal pathogenic Escherichia coli from retail chickens products. Antimicrob. Ag. Chemother. 47:2161-2168.

Joys T.M. 1985. The covalent structure of the phase-1 flagellar filament protein of Salmonella typhimurium and its comparison with other flagellin. J. Biol. Chem. 260:15758-15761

Kapatral V. \& Minnich S.A. 1995. Co-ordinate, temperature sensitive regulation of the three Yersinia enterocolitica flagellin genes. Mol. Microb. 17:49-56.

Kumar S., Tamura K. \& Nei M. 2004. MEGA3: Integrated software for Molecular Evolutionary Genetics Analysis and sequence alignment. Brief. Bioinf. 5:150-163.

Kuwajima G., Asaka J.I., Fujiwara T., Fujiwara T., Node K. \& Kondo E. 1986. Nucleotide sequence of the hag gene encoding flagellin of Escherichia coli. J. Bacteriol. 168:1479-1483.

Macnab R. 1992. Genetics and biogenesis of bacterial flagella. Annu. Rev. Genet. 26:131-158.

Mokady D., Gophna U. \& Ron E.Z. 2005. Extensive gene diversity in septicemic Escherichia coli strains. J. Clin. Microb. 43:66-73.

Moreno A.C., Guth B.E.C. \& Martinez M.B. 2006. Can the fliC PCRrestriction fragment length polymorphism technique replace classic serotyping methods for characterizing the $\mathrm{H}$ antigen of enterotoxigenic Escherichia coli strains? J. Clin. Microb. 44:1453-1458. 
Moura A.C., Irino K. \& Vidotto M. 2001. Genetic variability of avian Escherichia coli strains evaluated by enterobacterial repetitive intergenic consensus and repetitive extragenic palindromic polymerase chain reaction. Avian Dis. 45:173-181.

Ngeleka M., Kwaga J.K.P., White D.G., Whittam T.S., Riddell C., Goodhope R., Potter A.A. \& Allan B. 1996. Escherichia coli cellulitis in broiler chickens: clonal relationships among strains and analysis of virulence-associated factor of isolates from diseased birds. Infect. Immun. 64:3118-3126.

Popoff M.Y., Bockemuhl J. \& Brenner F.W. 1997. Supplement 1997 (no.41) to the Kauffmann-White scheme. Res. Microb. 149:601-604.

Ratiner Y.A. 1998. New flagellin-specifying genes in some Escherichia coli strains. J. Bacteriol. 180:979-984.

Reid S.D., Selander R.K. \& Whittam T.S. 1999. Sequence diversity of flagellin (fliC) alleles in pathogenic Escherichia coli. Infect. Immun. 181:153-160.

Rodriguez-Siek K.E., Giddings C.W., Doetkott C., Johnson T.J., Fakhr M.K. \& Nolan L.K. 2005. Comparison of Escherichia coli isolates implicated in humans urinary tract infection and avian colibacillosis. Microb. 151:2097-2110.

Sambrook J. \& Russel D.W. 2001. Molecular Cloning: A laboratory manual. 3rd ed. Cold Spring Harbor Laboratory Press, Cold Spring Harbor, New York, NY, p.999.
Silveira W.D., Ferreira A., Lancellotti M., Barbosa I.A.G.C.D., Leite D.S., Castro A.F.P. \& Brocchi M. 2002. Clonal relationships among avian Escherichia coli isolates determined by enterobaterial repetitive intergenic consensus. Vet. Microb. 89:323-328.

Stocki S.L., Babiuk L.A., Rawlyk N.A., Potter A.A. \& Allan B.J. 2002. Identification of genomic differences between Escherichia coli strains pathogenic for poultry and E. coli K-12 MG1655 using suppression subtractive hybridization analysis. Microb. Pathog. 33:289-298.

Strauch E. \& Beutin L. 2006. Imprecise excision of insertion elements IS5 from the fliC gene contributes to flagellar diversity in Escherichia coli. FEMS Microb. Lett. 256:195-202.

Tominaga A. 2004. Characterization of six flagellin genes in the $\mathrm{H} 3$, $\mathrm{H} 53$ and $\mathrm{H} 54$ standard strains of Escherichia coli. Gen. Genet. Syst. 79:1-8.

Wang L., Rothemund D., Curd H. \& Reeves P.R. 2003. Species-wide variation in the Escherichia coli flagellin (H-antigen) gene. J. Bacteriol. 185:2936-2943.

White D.G., Wilson R.A., Emery D.A., Kakambi V.N. \& Whittam T.S. 1993. Clonal diversity among strains of Escherichia coli incriminated in turkey colisepticemia. Vet. Microb. 34:19-34.

Winstanley C. \& Morgan J.A.W. 1997. The bacterial flagellin gene as a biomarker for detection, population genetics and epidemiological analysis. Microb. 143:3071-3084. 